\title{
WHICH IS MORE IMPORTANT TO THE SUCCESS OF AN ACQUISITION; ACQUIRER OR TARGET RESOURCES?
}

\author{
Ömer Faruk GENÇ 1
}

\author{
Received Date (Başvuru Tarihi): \\ Accepted Date (Kabul Tarihi): \\ Published Date (Yayın Tarihi):
}

$9 / 05 / 2020$

$29 / 06 / 2020$

$25 / 09 / 2020$

\begin{abstract}
Keywords:

Acquisition,

Resources,

Emerging Markets

JEL Codes:

F23, G34, M16

The resources of both acquirers and targets have been studied in terms of the drivers and success of acquisitions. Despite the large number of studies that have been conducted, we still do not know whose resources are more critical to the success of acquisitions. This study aims to examine the role of acquirer and target resources in the success of acquisitions. All acquisitions that took place in Turkey between 1990 and 2017 were analyzed to investigate the research question. The findings of a regression analysis of 425 acquisitions in this emerging market context reveal that acquirer resources are more critical than target resources in acquisition performance. The effects of resources on domestic and international acquisitions are also compared, and it is found that acquirer resources are more critical in domestic acquisitions, whereas target resources are more important in international acquisitions. The implications of these findings are discussed in terms of information asymmetry and post-acquisition integration issues, and directions for future research are suggested.
\end{abstract}

\section{ALICI VE SATICI ŞİRKETLERIN KAYNAKLARININ ŞİRKET SATIN ALMALARININ BAŞARISINDAKİ ROLÜ}

$\ddot{O Z Z}$

\section{Anahtar Kelimeler:}

Firma Satın Almalar,

Kaynaklar,

Gelişen Pazarlar

JEL Kodlarn:

F23, G34, M16
Şirket satın almalarda hem alıcı hem de satıcı şirketlerin kaynakları, satın almaların gerek gerekçeleri, gerekse de sonuçları açısından çalışılmıştır. Yapılan çok sayıda çalışmaya rağmen, hangi kaynakların satın almalarm başarısında daha önemli olduğu net değildir. Bu çalı̧̧manın amacı alıcı ve satıcıların kaynaklarının satın almaların başarısı üzerindeki rolünü incelemektir. Bu konuyu incelemek için 1990 ve 2017 yılları arasında Türkiye`de gerçekleşmiş tüm satın almalar analiz edilmiştir. Gelişmekte olan pazarlarda yapılan 425 şirket satın alma üzerine yapılan regresyon analizleri sonucu, alıcı şirketlerin kaynaklarının satıcı şirketlerinkinden başarıda daha önemli olduğu gösterilmiştir. Kaynakların şirket satın alma üzerine olan etkisi yerel ve uluslararası satın almalar arasında da karşılaştırılmış ve alıcı şirketlerin kaynaklarının ulusal satın almalarda daha etkili olduğu, satıcı şirketlerin kaynaklarının da uluslararası satın almalarda daha önemli olduğu gösterilmiştir. Çalışma bu bulguların literatür ve şirketler için yansımalarını yanı sıra gelecekteki çalı̧̧alar için öneriler içermektedir.

\footnotetext{
${ }^{1}$ Assistant Professor, Williamson College of Business Administration, Youngstown State University, Youngstown, OH 44555. Phone: +1 330-303-3692, ofgenc@ysu.edu https://orcid.org/0000-0001-7747-1095
} 


\section{INTRODUCTION}

Acquisitions have become increasingly popular and are being used extensively by firms. Some various motivations and drivers lead firms to engage in acquisitions, such as acquiring the technology of a target firm (Yu, Dang, \& Motohashi, 2019), gaining ownership of valuable resources (Huyghebaert \& Luypaert, 2010), indulging a CEO's self-interest (Lee, Cho, Arthurs, \& Lee, 2019), diversifying (Doukas \& Kan, 2008), and maximizing financial resources (Yang, Guariglia, \& Guo, 2019). The evidence is mixed about whether acquirers achieve their goals in acquisitions; studies have documented positive, negative, and insignificant outcomes (King, Dalton, Daily, \& Covin, 2004). Acquiring the resources of the target firm and creating synergies with the acquirer's resources are two of the core goals of acquisitions (Blonigen, 1997). Ambiguous findings concerning the outcomes of acquisitions, combined with the importance of resources as an antecedent of acquisitions, have created an interest in the relationships between acquisitions and resources.

The resource-based view (RBV) views the ownership of resources as the primary determinant of creating value (Barney, 1991). Following the RBV's arguments, a stream of research has proposed external linkages as a means of obtaining valuable resources and skills in order to increase competitiveness (Dyer, Singh, \& Hesterly, 2018; Dyer \& Singh, 1998). Acquisitions are among the most commonly used method for obtaining resources that are valuable but hard for a company to develop itself, as they offer immediate ownership of those resources (Manne, 1965). Therefore, the resources of both acquirers and targets have received significant attention in acquisition research (e.g., Zhou, 2011). Target resources have been studied as a motivation for acquirers and a critical factor in the target selection process (Muratova, 2015). Dunning (1998) lists seeking resources and materials as one of the reasons for firms' international investment decisions. The types and amounts of target resources have also been analyzed in terms of their effects on acquisition success.

On the other side, acquirer resources also affect both the likelihood and outcomes of acquisitions. In his classical, eclectic paradigm, Dunning (1981) views the ownership of resources as a requirement for investment initiatives, including acquisitions. Given that acquisitions are the most popular means of foreign expansion 
(He, Boateng, \& Agyenim, 2019), the resources of an acquirer are considered to be critical to the success of an international acquisition (Caves, 2007). Another group of studies have examined the complementarity of acquirer and target resources, and the role each plays in the success of an acquisition, and have found complementarity to be the key to positive performance after an acquisition (King, Slotegraaf, \& Kesner, 2008; Makri, Hitt, \& Lane. 2010). Despite a large number of studies that examine resources from an acquisition perspective, we still do not know whose resources are more critical to the success of an acquisition. The majority of studies have focused on either the acquirer's or the target's resources. Others have looked at the complementarity of those resources and their effects on performance. To the best of our knowledge, no study examines both acquirer and target resources at the same time and compare them. The goal of this study is to fill this gap by examining the resources of both acquirer and target to see, which has more influence on post-acquisition performance.

Acquisitions are analyzed in the context of an emerging market, Turkey, to see which resources were more important to the success of the acquisitions. Emerging markets have been very active in acquisitions (Popli, Ladkani, \& Gaur, 2017; He et al., 2019), and Turkey is a fitting context in which to study them because it has become home to an increasing number, both domestic and international (Genc \& Kalkan, 2018). Turkey, located at the intersection of Europe and Asia, has a critical role in serving those markets. Turkey's being part of the European Economic Union and having an economic transformation after its financial crisis in 2001 have both triggered the flow of capital into the country (Y1ldırım, 2017), which makes it a great context to study the phenomenon of acquisitions mainly due to interest by multinational enterprises in the region (Demirbag, Tatoglu, \& Glaister, 2008). This has resulted in a stream of literature that looks at acquisitions in Turkey. Majority of those acquisition studies conducted in the Turkish context either are case-based (e.g. Semerciöz \& Çakınberk, 2003) or analyzed stock market reactions (e.g. Akben \& Altık, 2011). The role of resources in Turkish acquisitions have not been studied, and this study aims to fill that gap.

This study found that acquirer resources have a positive effect on postacquisition performance, whereas target resources have a negative effect. This result, which is contrary to the findings in the literature, can be explained in terms of 
information asymmetry and the overvaluation of targets. Besides, domestic and international acquisitions are compared, as companies face more challenges to integration, and hence synergy creation, in international deals than in domestic acquisitions (Bertrand \& Zitouna, 2008). The findings of the study indicate that acquirer resources are more important in domestic acquisitions than in foreign acquisitions; however, the effect of target resources on domestic acquisitions is more damaging than on international acquisitions.

This study contributes to the literature in several ways. First, it extends the application of the resource-based view to acquisitions by examining acquirer and target resources together. This enables us to see which resources are more important to the success of acquisitions. Second, the effects of resources on acquisition success in an emerging market context are analyzed, which is an understudied area. This is the first study to examine these effects in the context of Turkish acquisitions. Lastly, the comparison of domestic and international acquisitions enables us to see how the effects of resources vary between these two types of acquisitions, which has not been previously studied. In these ways, this study shed light on acquisition research, especially from the resource-based perspective.

The rest of the paper proceeds as follows. In the next section, a theoretical and empirical literature review is provided along with hypotheses. Then, data and method are explained, followed by a report of the empirical analysis and findings. The paper ends with the conclusion, which includes the recommendations, contributions, and limitations of the study, and suggests directions for future research.

\section{THEORETICAL AND EMPIRICAL LITERATURE REVIEW}

In an increasingly competitive business environment, firms look for ways to enhance their competitive advantage. In this competitive landscape, the acquisition is viewed as a critical strategy. Firms use acquisitions to increase their market share and power, enhance their economies of scale, eliminate competitors, learn, creating synergies, etc. (Hussinger, 2010; Lin, Peng, Yang, \& Sun, 2009; Schmitz \& Sliwka, 2001; Zollo \& Meier, 2008; Gupta \& Gerchak, 2002). Despite the ambitious goals and expectations associated with acquisitions, the empirical evidence is mixed about their 
outcomes (Genc, 2016). This has led to a stream of literature that looks at the success factors in acquisitions. Several factors have been proposed to affect the performance outcomes of acquisitions, including acquisition experience (Haleblian \& Finkelstein, 1999; Vermeulen \& Barkema, 2001), integration (Schweiger \& Lippert, 2005), institutional variables (Brockman, Rui, \& Zou, 2013), and the resources of acquirers and targets. This study focuses on the impacts of the acquirer and target resources on the success of acquisitions in emerging markets, as there is a pressing need to understand the dynamics of the acquisitions taking place in these markets (Chen, Hua, \& Boateng, 2017; Liou, Rao-Nicholson, \& Sarpong, 2018).

\subsection{Resources and Acquisitions}

The resource-based view of firms views resources as the main determinants of competitive advantage and success (Wernerfelt, 2011). The main argument in this stream of research has been that firms engage in acquisitions to gain access to the resources of target firms (Delios, Gaur, \& Kamal, 2009). Target resources have received the most attention because acquiring such resources is among the top motivations of acquisitions (Gubbi \& Elango, 2016). There is also empirical evidence of the potential of synergies created after an acquisition (Blonigen, 1997). Acquisitions have primarily been used to access resources in foreign markets that firms find hard to develop themselves (Rui \& Yip, 2008). In a similar vein, resources are linked to the outcomes of acquisitions. It has been argued that acquirers look for complementary resources (Harrison, Hitt, Hoskisson, \& Ireland, 2001) and that acquisitions perform better when acquirer and target resources are more complementary (Colombo \& Rabbiosi, 2014; Chen, Meng, \& Li, 2018). However, difficulties with post-acquisition integration are an obstacle to utilizing target resources (Schweiger \& Lippert, 2005; Puranam, Sing, \& Zollo, 2006); firms that can manage post-acquisition integration successfully enjoy more positive outcomes (Kim \& Finkelstein, 2009; Jemison \& Sitkin, 1986). Although both acquirer and target resources have been studied in terms of how they affect acquisitions, we still do not know which is more critical to the success of an acquisition. This study aims to fill this gap by simultaneously analyzing both types of resources to shed light on the relative importance of each. 


\subsection{The Effects of Acquirer Resources on Acquisition Success}

The eclectic paradigm views the ownership of valuable resources as a driver for investment via acquisitions (Dunning, 1981). Both the tangible and intangible resources of a firm increase the likelihood of an acquisition (Madhok, 1997). Nevertheless, most of the acquisition literature has analyzed acquirer resources as a critical success factor in acquisitions. There are several challenges firms face in the post-acquisition integration process, which hinder the likelihood of creating synergies. Acquisition experience helps firms to manage this process better and improve postacquisition performance (Al-Laham, Schweizer, \& Amburgey, 2010; Haleblian \& Finkelstein, 1999). The acquirer's resources and experience are instrumental in overcoming the challenges that arise from information asymmetry between the acquirer and the target (Popli et al., 2017). Managerial capabilities also help firms to manage this complex process more effectively (Boateng, Du, Bi, \& Lodorfos, 2019) and to achieve more significant growth from an acquisition (Lamont, King, Maslach, Schwerdtfeger, \& Tienari, 2019). The integration of target resources with acquirer resources enables the creation of synergies, but the acquirer's assimilative capacity affects how well target resources can be utilized and, in turn, acquisition success (Gubbi \& Elango, 2016). Even before an acquisition takes place, there are potential benefits to be had from the acquirer's resources. Resources like reputation help acquirers to convince targets more efficiently and result in less resistance by target employees after being acquired (Edi Basri, \& Arafah, 2020). All of these factors lead to the first hypothesis, which addresses the positive effect of acquirer resources on acquisition success.

$\mathrm{H}_{1}$ : Acquirer resources have a positive effect on acquisition success.

There is well-established literature about how necessary acquirer resources are to the success of acquisitions, albeit the majority of studies analyze acquisitions as a whole. However, there are significant differences between international and domestic acquisitions, which are distinguished in terms of motivations, success factors, and outcomes (Genc, 2016). Cultural differences, geographic distance, and institutional differences between the acquirer's and the target's home markets create challenges at 
the different stages of acquisition (Boateng et al., 2019; Owen \& Yawson, 2010; Davies, Desbordes, \& Ray, 2018; Dhanaraj, Lyles, Steensma, \& Tihanyi, 2004). These challenges affect the potential synergies to be created from the integration of acquirer and target resources. Therefore, there is a need to see how resources affect acquisition success in both international and domestic acquisitions, which led us to make a comparison between the two.

One of the challenges in managing an acquisition is information asymmetry between the acquirer and the target; this is more severe in international acquisitions and especially in emerging markets (Akerlof, 1970; Khanna \& Palepu, 1997). Acquirer resources play a critical role in overcoming challenges like this. Foreign acquirers are larger companies with more diversification and international experience on average (Genc \& Kalkan, 2018). These characteristics help foreign acquirers to minimize problems associated with information asymmetry. For instance, Popli et al. (2017) demonstrated that multinational firms could deal with the problem of information asymmetry by taking advantage of the social capital that they have developed through business groups. Because foreign acquirers in emerging markets are more extensive and more diversified, they have more managerial talent as a critical resource, which helps them to manage complex processes more effectively. The managerial talent and experience of foreign acquirers result in a more effective post-acquisition integration process, which is reflected in more significant improvements in productivity after an international acquisition as opposed to a domestic one (Conyon, Girma, Thompson, \& Wright, 2002). All of these factors, combined with more substantial financial resources, enable foreign acquirers to do better due diligence regarding the target firm, which affects the success of acquisition performance (Wangerin, 2019). Another way acquirer resources can be more influential in acquisitions is through diversity. Foreign acquirers are more diverse in general, and they bring a range of different skills and resources to the situation, compared to acquirers in domestic acquisitions, where the companies are from the same culture. This enhanced cultural heterogeneity can boost creativity (Cox, 1991). The diversity created after an international acquisition provides target companies with different viewpoints, ways of thinking, and solutions to important problems (Gomez-Mejia \& Palich, 1997). Besides, foreign acquirers have 
affiliates in different parts of the world and the ability to utilize the resources of those affiliates when they are needed (Piepenbrink \& Gaur, 2013). All these assert that acquirer resources are more important and useful for the success of acquisitions in international acquisitions than in domestic acquisitions.

$\mathrm{H}_{2}$ : Acquirer resources have a more positive effect on acquisition success in international acquisitions than in domestic acquisitions.

\subsection{The Effects of Target Resources on Acquisition Success}

Obtaining resources and strategic assets is one of the main drivers of investment, especially in international transactions (Dunning, 1993). Firms need to get critical resources outside their boundaries to remain competitive (Hitt, 2016). Acquisitions provide a fast way to get resources that are difficult to develop internally (Gubbi, Aulakh, Ray, Sarkar, \& Chittoor, 2010). These resources can benefit acquirers by increasing sales via the networks and connections of the target company, integrating the technology and know-how of the target company with the resources of the acquirer, using the target's expertise about a specific market or technology, and so forth. That is why acquirers view target executives as key people whose retention enhances acquisition performance (Butler, Perryman, \& Ranft, 2012). Especially when it enters a new market, a firm will use the reputation and the customer base of the target (Saxton \& Dollinger, 2004). All of this leads to the hypothesis about the positive effects of target resources on acquisition success.

$\mathrm{H}_{3}$ : Target resources have a positive effect on acquisition success.

The motivation of acquirers to obtain target resources and create synergies by combining them with their resources is well established in the literature (e.g., Maharaj \& Reddy, 2013; Blonigen \& Taylor, 2000). However, the evidence is mixed about the effects of target resources (King et al., 2008; Delios et al., 2009; Gubbi \& Elango, 2016). One explanation for these inconclusive results is that the effects of target resources might vary with the type of acquisition. In this study, the aim is to distinguish international and domestic acquisitions to see whether the effects of target resources on acquisition success differ between the two types of acquisitions. 
There are several additional challenges posed by international acquisitions, such as cultural distance, which can lead to lower performance (Boateng et al., 2019). These challenges can affect the benefits an acquirer gets from target resources in an international acquisition. One such consideration is the accurate identification of the new resources (Cooney, Moeller, \& Stegemoller, 2009). Foreign acquirers have a more challenging time evaluating and assessing a target's resources, due to geographic and cultural distance, and to differences between institutional factors in the home and host countries (Mukherji, Mukherji, Dibrell, \& Francis, 2013). This information asymmetry between the acquirer and target is offered as one explanation for acquisition failures (Haspeslagh \& Jemison, 1991). Combined with differences between markets across countries, it can lead to a misevaluation of target resources. Another challenge foreign acquirers face post-acquisition integration problems, which might compromise the benefits derived from target resources. For instance, the employees of a target company feel increasingly insecure after an acquisition, which affects their cooperative behaviour (Guerrero, 2008) and lowers the likelihood that they will be retained (Krug \& Hegarty, 1997). Cultural distance, which is usually the case in an international acquisition, harms communication between the partners (Reus \& Lamont, 2009) and makes the integration process more difficult (Stahl \& Voigt, 2008). Both information asymmetry and integration are less of an issue in domestic deals, which leads to hypothesize that foreign acquirers benefit less from target resources than domestic acquirers.

$\mathrm{H}_{4}$ : Target resources have a more positive effect on acquisition success in domestic acquisitions than in international acquisitions.

\subsection{Comparison of Acquirer and Target Resources}

The importance of acquirer and target resources has been studied extensively in the acquisition literature, but not many studies look at their relative importance to acquisition success. So, this study aims to fill the gap by investigating whether acquirer or target resources have more influence on the success of an acquisition. Even in domestic acquisitions, there is information asymmetry between the acquirer and the target (Schijven \& Hitt, 2012), which limits the ability of acquirers to assess target 
resources and makes it harder to benefit from them. However, firms have a better knowledge of their resources and how they can be used to enhance the performance of targets. Another factor that makes it challenging to benefit from target resources is post-acquisition integration problems (Lamont et al., 2019). Many potentially valuable target resources are intangible, such as business networks, employees' experiences, and local knowledge. Some acquisitions result in high turnover and resistance on the part of target employees to share knowledge (Steigenberger \& Mirc, 2019).

In some cases, key employees leave the acquired company, which limits the acquirer's ability to retain critical know-how and maximize the new resources. Besides, the transfer of capabilities is negatively affected by integration issues (Colman, 2020). For all of these reasons, acquirer resources are more critical to the success of an acquisition than the resources of a target firm.

$\mathrm{H}_{5}$ : Acquirer resources are more important than target resources for the success of acquisitions.

\section{DATA AND METHOD}

\subsection{Sample}

Our sample consists of acquisitions that occurred in one of the emerging markets, Turkey between 1990 and 2017. Turkey is used as the context of the study, as the country has been home to an increasing number of M\&As, involving both domestic and foreign deals (Genc \& Kalkan, 2018). Acquisition data is gathered from the Thomson Financial SDC Platinum Database and WRDS Compustat database is used for firm-level variables. There are 425 acquisitions in the dataset. A total of 254 of these transactions (60\%) are domestic acquisitions, in which a Turkish company acquired a Turkish target. The other $40 \%$ of the deals (171) are acquisitions in which a foreign acquirer took over a Turkish company. The analyses are conducted on the whole sample of domestic and foreign acquisitions.

\subsection{Operationalization of Variables}

\subsubsection{Dependent Variables}

The goal of this study was to examine the performance of acquirers from various perspectives to have a clearer picture of the impact of resources. Four 
dependent variables were used to assess the performance of acquisitions. The first variable is sales growth in the year when the acquisition took place, as growth is one of the most important motivations for pursuing an acquisition. Three measures are used for financial performance; profitability, net incomes scaled by total sales, return on assets (ROA), a measure commonly used to assess performance, and the EBITDA margin; the earnings before interest, taxes, and depreciation (EBITDA), scaled by total assets. All analyses were conducted using sales growth and three financial performance measures.

\subsubsection{Independent Variables}

The main point of interest in this study is the resources of acquirer and target companies. Intangibles of a firm are used to measure the resources of the acquirers, which is operationalized by calculating the value of intangible assets as a percentage of the total assets for the year before the acquisition. Intangible assets encompass most of the intellectual properties of a company, such as patents, technologies, etc.; it is a commonly used proxy for the resources of companies. On the other hand, goodwill of the acquirer after the acquisition is used as a proxy for the resources of the target company. As per the definition of the variable in the dataset (WRDS Compustat), goodwill represents the excess cost over the equity of an acquired company. Acquirers usually pay a premium for the acquisition of a target to compensate for the resources of the acquired company (Lee et al., 2019). The premium, which is usually associated with the money paid for an excess of market value, is added to goodwill. Goodwill reported after an acquisition reflects the number of resources possessed by the target; therefore, goodwill was used as a proxy for the resources of the target company. 
Table 1. Definition of Variables

\begin{tabular}{ll}
\hline Variable & Measurement \\
\hline Profitability & $\begin{array}{l}\text { Net income in \$ million scaled by total sales at the end of the acquisition year. } \\
\text { The annual growth in total revenue at the end of the acquisition year } \\
\text { compared to the pre-acquisition year }\end{array}$ \\
Sales Growth & $\begin{array}{l}\text { Net income in \$ million scaled by total assets } \\
\text { Return on Asset (ROA) }\end{array}$ \\
EBITDA Margin & $\begin{array}{l}\text { Earnings before interest, taxes, and depreciation (EBITDA) in } \$ \text { million scaled } \\
\text { by total sales }\end{array}$ \\
Size & $\begin{array}{l}\text { Natural log of total assets in } \$ \text { million } \\
\text { Leverage }\end{array}$ \\
Capital Expenditures & $\begin{array}{l}\text { Capital expenditures in } \$ \text { million scaled by total sales. } \\
\text { Goodwill of the acquirer in } \$ \text { million scaled by total assets for the acquisition } \\
\text { Gear }\end{array}$ \\
Intangibles & $\begin{array}{l}\text { Intangibles assets of the acquirer in } \$ \text { million scaled by total assets for the } \\
\text { year before the acquisition. }\end{array}$
\end{tabular}

\subsubsection{Control Variables}

Three control variables are used as representing factors that have the potential to influence the success of an acquisition. Size, which is measured in terms of total assets, is a common control variable that is used in many studies. The leverage of the acquirer is used to control for its effect on performance, and finally, capital expenditures scaled by total assets is included. In general, companies are expected to perform better when they invest more in capital expenditures, so this critical variable is also controlled. The definitions of all of the variables used in the study are provided in Table 1.

\subsection{Method}

The goal of the study was to understand the impact of acquirer and target resources on the success of acquisitions. To achieve this goal and test the hypotheses, multiple regression analyses are conducted. Four aspects of acquisition success were used as dependent variables, as indicated above, while acquirer and target resources were the key points of interest regarding the independent variables. The regressions were conducted with heteroscedasticity-robust standard errors, and all of the variables are winsorized in the study to avoid extreme cases. A year and industry effects are 
controlled at the two-digit SIC level. The analysis is conducted on three scales: all acquisitions, foreign acquisitions, and domestic acquisitions.

\section{EMPIRICAL ANALYSIS}

\subsection{Descriptive Statistics}

The descriptive statistics for all the variables and the correlations between them are presented in Table 2. The sample consists of 425 acquisitions that occurred in Turkey. A total of 254 (60\%) of the transactions were domestic, that is, between Turkish acquirers and targets; the remaining 40\% (171 deals) consisted of foreign companies acquiring Turkish targets. The number of observations was lower in the regression analyses due to missing data for the variables. The acquirers showed positive performance on all the dimensions used, but there were variations among performance indicators in terms of standard deviation. There were significant correlations between some dependent variables, such as the EBITDA margin and profitability. However, these significant correlations did not affect the findings, as each performance indicator is used in a different model. The rest of the correlations are also provided in Table 2; they did not have a significant effect on the analysis.

Table 2. Descriptive Statistics and Correlations

\begin{tabular}{|c|c|c|c|c|c|c|c|c|c|c|c|c|}
\hline & & Mean & $\begin{array}{l}\text { Std. } \\
\text { Dev. }\end{array}$ & 1 & 2 & 3 & 4 & 5 & 6 & 7 & 8 & 9 \\
\hline Profitability & 1 & 0.05 & 0.40 & & & & & & & & & \\
\hline Sales Growth & 2 & 0.25 & 0.91 & $-0.209^{*}$ & 1 & & & & & & & \\
\hline $\begin{array}{l}\text { Return on Asset } \\
\text { (ROA) }\end{array}$ & 3 & 0.03 & 0.09 & $0.5282^{*}$ & 0.0205 & 1 & & & & & & \\
\hline EBITDA Margin & 4 & 0.11 & 0.73 & $0.6660^{*}$ & $-0.2084^{*}$ & $0.2613^{*}$ & 1 & & & & & \\
\hline Size & 5 & 7.98 & 3.56 & 0.0901 & -0.075 & 0.0849 & $0.1629^{*}$ & 1 & & & & \\
\hline Leverage & 6 & 0.16 & 0.14 & 0.0341 & -0.0313 & $-0.1825^{*}$ & 0.0815 & 0.0867 & 1 & & & \\
\hline $\begin{array}{l}\text { Capital } \\
\text { Expenditures }\end{array}$ & 7 & 0.13 & 0.22 & $-0.477^{*}$ & $0.2427^{*}$ & $-0.1643^{*}$ & $-0.484^{*}$ & $-0.1621^{*}$ & $0.1645^{*}$ & 1 & & \\
\hline Goodwill & 8 & 0.08 & 0.12 & -0.0414 & -0.0737 & 0.0335 & -0.0001 & -0.0377 & 0.0782 & $-0.179^{*}$ & 1 & \\
\hline Intangibles & 9 & 0.17 & 0.25 & 0.0137 & 0.0318 & 0.1087 & 0.0425 & -0.0182 & $0.1544^{*}$ & $-0.224^{*}$ & $0.6104^{*}$ & 1 \\
\hline
\end{tabular}

${ }^{* * *},{ }^{* *}$, and $*$ represent statistical significance at the $1 \%, 5 \%$, and $10 \%$ levels, respectively.

Source: Created by the author. 


\subsection{Effect of Acquirer Resources on Acquisition Success}

The first set of analyses are about the effects of acquirer resources on acquisition success. Hypotheses 1 and 2 are tested by examining the impact of acquirer resources on post-acquisition performance. First, this analysis was conducted on all the acquisitions in the sample to determine the overall effect of acquirer resources. As can be seen in Table 3, acquirer intangible resources have a positive and significant coefficient in all four models. This indicates that acquisitions become more successful when the acquirers have more resources, which supports Hypothesis 1.

Next, the effects of acquirer resources were examined for the two types of acquisitions, domestic and international, to determine in which set of samples they exerted the most significant effect, the results of which are presented in Table 4. Acquirer resources have a positive and significant effect in two of the four models, for sales growth and EBITDA margin. The same regressions are run on the domestic samples. As can be seen in Table 5, acquirer resources affected all of the performance indicators positively and significantly. This indicates that acquirer resources are more critical to the success of domestic acquisitions than to the success of foreign acquisitions of Turkish companies. A similar picture is observed in the comparison of the coefficients of acquirer resources from all of the models. For instance, the coefficient of acquirer resources is 0.23 for sales growth in foreign acquisitions (Table 4) compared to 1.11 for sales growth in domestic acquisitions (Table 5). These numbers support the main finding, that acquirer resources have a more positive effect in domestic acquisitions; however, these results do not provide support hypothesis 2 and run counter to the expectations as well as to the literature. One explanation for this finding is that there are fewer integration issues in domestic acquisitions, which makes it easier to utilize acquirer resources in conjunction with those of a target company. Because the work cultures are similar, the managers of a target company are more likely to be retained in a domestic acquisition, which contributes to post-acquisition success through better technology and knowledge transfer (Ranft \& Lord, 2000). Finding a target with resources that complement the acquirer's resources is vital for the success of an acquisition (Makri et al., 2010). 
Furthermore, the lower amount of information asymmetry in domestic deals can help domestic acquirers find better targets to combine resources with (Chang \& Tsai, 2013). Besides, the resources of the acquirer, such as its experience and network, may be of less use in a foreign market and thus reduce the benefits to be gained from them. Even transferring relevant resources to another country can be problematic.

Table 3. Impact of Resources - All Acquisitions

\begin{tabular}{|c|c|c|c|c|}
\hline & Profitability & Sales Growth & $\begin{array}{c}\text { Return on Asset } \\
\text { (ROA) }\end{array}$ & EBITDA Margin \\
\hline & $(1)$ & (2) & (3) & $(4)$ \\
\hline \multirow[t]{2}{*}{ Size } & 0.00 & -0.01 & 0.001 & 0.01 \\
\hline & -0.03 & $(-0.85)$ & -0.32 & -1.63 \\
\hline \multirow[t]{2}{*}{ Leverage } & 0.151 & -0.394 & $-0.185^{* * *}$ & $0.847^{*}$ \\
\hline & -0.7 & $(-1.16)$ & $(-2.69)$ & -1.81 \\
\hline \multirow[t]{2}{*}{ Capital exp. } & $-0.576^{* *}$ & $0.887^{* * *}$ & -0.019 & -1.203 \\
\hline & $(-2.09)$ & -2.9 & $(-0.62)$ & $(-1.62)$ \\
\hline \multirow[t]{2}{*}{ Intangibles } & $0.185^{* * *}$ & $0.707^{* *}$ & $0.099^{* * *}$ & $0.227^{*}$ \\
\hline & -3 & -2.33 & -2.91 & -1.68 \\
\hline \multirow[t]{2}{*}{ Goodwill } & $-0.547^{* * *}$ & $-0.897^{*}$ & $-0.117^{* *}$ & $-0.855^{\star *}$ \\
\hline & $(-3.19)$ & $(-1.66)$ & $(-1.98)$ & $(-2.05)$ \\
\hline \multirow[t]{2}{*}{ Constant } & 0.089 & 0.148 & $0.055^{\star *}$ & 0.053 \\
\hline & -1.39 & -1.1 & -2.34 & -0.79 \\
\hline$N$ & 216 & 231 & 216 & 231 \\
\hline Adj. $R^{2}$ & 0.176 & 0.136 & 0.113 & 0.231 \\
\hline
\end{tabular}

\subsection{Effect of Target Resources on Acquisition Success}

Another goal of the study is to examine how the resources of target companies affect the success of acquisitions (H3) and whether there would be a difference in this effect between domestic and foreign acquisitions (H4). In order to test hypothesis 3 , regression analyses were conducted on all of the acquisitions, the results of which are presented in Table 3. Target resources have negative and significant coefficients in all of the models, which indicates they harm post-acquisition performance. This is also contrary to the expectations and does not provide support for hypothesis 3. 
Table 4. Impact of Resources - International Acquisitions

\begin{tabular}{lcccc}
\hline & Profitability & Sales Growth & $\begin{array}{c}\text { Return on Asset } \\
(\text { ROA })\end{array}$ & $\begin{array}{c}\text { EBITDA Margin } \\
\end{array}$ \\
& $(1)$ & $(2)$ & $(3)$ & $(4)$ \\
\hline Size & -0.003 & -0.008 & $-0.004^{* *}$ & -0.001 \\
Leverage & $(-0.70)$ & $(-0.90)$ & $(-2.54)$ & $(-0.14)$ \\
& $0.384^{*}$ & 0.017 & 0.043 & $0.737^{*}$ \\
Capital exp. & -1.91 & -0.06 & -0.72 & -1.95 \\
& $-1.523^{* * *}$ & $1.740^{* * *}$ & $-0.125^{* * *}$ & $-3.903^{* * *}$ \\
Intangibles & $(-6.29)$ & -4.5 & $-6.07)$ & $-4.93)$ \\
& 0.003 & $0.239^{*}$ & 0.018 & $-0.301^{*}$ \\
Goodwill & -0.06 & -1.76 & -0.85 & $(-1.78)$ \\
& $-0.280^{* *}$ & -0.116 & -0.075 & 0.049 \\
Constant & $(-2.14)$ & $(-0.58)$ & $(-1.62)$ & -0.19 \\
& $0.141^{* *}$ & -0.004 & $0.088^{* * *}$ & $0.324^{* *}$ \\
$N$ & -2.08 & $(-0.03)$ & -3.58 & -2.29 \\
Adj. $R^{2}$ & 79 & 89 & 79 & 89 \\
\hline
\end{tabular}

The $\mathrm{t}$-values associated with each coefficient are provided in parentheses. ${ }^{* * *},{ }^{* *}$, and ${ }^{*}$ represent statistical significance at the $1 \%, 5 \%$, and $10 \%$ levels, respectively.

Source: Created by the author.

Table 5. Impact of Resources - Domestic Acquisitions

\begin{tabular}{lcccc}
\hline & Profitability & Sales Growth & $\begin{array}{c}\text { Return on Asset } \\
(\text { ROA })\end{array}$ & $\begin{array}{c}\text { EBITDA Margin } \\
(3)\end{array}$ \\
\hline Size & $(1)$ & $(2)$ & $(3)$ & $(4)$ \\
Leverage & 0.001 & -0.007 & 0.002 & $0.016^{* * *}$ \\
& -0.22 & $(-0.41)$ & -0.55 & -2.63 \\
Capital exp. & -0.021 & -0.386 & $-0.253^{* * *}$ & 0.597 \\
& $(-0.08)$ & $(-0.92)$ & $(-3.19)$ & -1.02 \\
Intangibles & -0.373 & $0.695^{* *}$ & 0.014 & -0.718 \\
& $(-1.23)$ & -2.29 & -0.36 & $(-0.92)$ \\
Goodwill & $0.209^{* * *}$ & $1.111^{* *}$ & $0.130^{* *}$ & $0.322^{* * *}$ \\
& -2.96 & -2.19 & -2.56 & -2.91 \\
Constant & $-0.517^{*}$ & -1.398 & -0.087 & $-1.262^{*}$ \\
& $(-1.67)$ & $(-1.48)$ & $(-0.64)$ & $(-1.79)$ \\
$N$ & 0.085 & 0.138 & 0.048 & 0.012 \\
Adj. $R^{2}$ & -1.15 & -0.85 & -1.62 & -0.2 \\
& 137 & 142 & 137 & 142 \\
& 0.073 & 0.114 & 0.148 & 0.129 \\
\hline
\end{tabular}

The $t$-values associated with each coefficient are provided in parentheses. ${ }^{* * *},{ }^{* *}$, and ${ }^{*}$ represent statistical significance at the $1 \%, 5 \%$, and $10 \%$ levels, respectively.

Source: Created by the author. 
One of the explanations for this finding is that acquirers might overvalue the resources of a target, which results in an overestimation of the potential synergies that can be created by an acquisition. Another explanation can be related to information asymmetry between the acquirer and the target and to post-acquisition integration issues. Information asymmetry has been viewed as one of the obstacles to acquisition success; it can lead to an overestimation of target resources, which is reflected in the measure used-goodwill. This, combined with overconfidence on the part of acquirer managers (Ismail, 2008), can produce a negative effect on acquisition success.

Identical analyses were conducted with two separate samples of foreign and domestic acquisitions to test hypothesis 4 . The results for the effects of target resources on foreign acquisitions are presented in Table 4 . The target resources' coefficients are significant only in model 1, where profitability is used as the dependent variable. In Table 5, which provides the results for the domestic acquisition sample, there are two significant coefficients for target resources (profitability and EBITDA margin). The results show a more negative effect on domestic acquisitions than in foreign acquisitions. A comparison of the coefficients from the two samples supports the central finding. For instance, target resources have a coefficient of -0.28 in the foreign acquisition sample and a coefficient of -0.51 in the domestic sample. The negative effect is more substantial in domestic acquisitions. Another interpretation of these results could be that target resources have a less positive effect in domestic acquisitions than in foreign acquisitions, which does not provide support for hypothesis 4 . The more negative effect of target resources in domestic acquisitions could be due to the lack of experience of domestic companies with emerging markets, which might influence how an acquirer selects a target and conducts the acquisition. Foreign acquirers, which are mostly big multinational enterprises, have more experience with acquisitions and do better in terms of selecting targets and managing the acquisition process (Rugman \& Verbeke, 2004), which could explain the more positive outcomes. The higher level of experience of foreign acquirer also leads them to do a better job of utilizing target resources compared to domestic acquisitions (Rugman \& Verbeke, 2004). 
Moreover, foreign acquirers have more resources to allocate to consulting in the due diligence process, which helps them to identify target resources better than domestic acquirers. Due to geographic distance, the integration process is slower after an international acquisition, which can mitigate employee resistance (King et al., 2020). This could be another reason for why international acquirers benefit more from target resources.

\subsection{Acquirer versus Target Resources}

Lastly, the effects of acquirer and target resources are compared to investigate whether they differed in their impact on the success of an acquisition. The comparison was made in the first analysis, the results of which are presented in Table 3. All of the acquisitions were included in these analyses, and both acquirer and target resources were considered. The results show that acquirer resources have a positive and significant effect on acquisition success, which was measured in terms of intangibles, whereas target resources have a negative effect. This result supports hypothesis 5 and indicates that acquirer resources are more critical to the success of an acquisition. Acquirers face several challenges in identifying, valuing and utilizing target resources. These challenges lower the likelihood of utilizing and benefiting from target resources, which can explain relatively greater importance of acquirer resources than target resources.

\section{CONCLUSION}

Mergers and acquisitions have been studied through different lenses, including the resource-based view, which posits that resources of a firm are essential in acquisitions, both as a driving force and a success factor. Possessing resources and complementing them with the resources of a target firm creates synergies and leads to successful M\&As. despite well-established literature in M\&As about acquirer and target resources, it is still not clear which of these resources is more critical to the success of an acquisition. This study fills this gap by comparing acquirer and target resources to see how they affect acquisition success. Moreover, it examines the impact 
of acquirer and target resources for both foreign and domestic acquisitions to see whether this impact differs between the two types of acquisitions.

Consistent with the literature, the results of this study show that acquirer resources have a positive effect on acquisition success. However, it appears that acquirer resources have a more positive effect on domestic acquisitions than in international acquisitions, which is contrary to expectations. The results of the analysis of target resources also revealed findings contrary to the literature. Unlike those of many studies in the literature (Gubbi et al., 2010), the findings show a negative effect of target resources on acquisition success. The comparison of this effect between domestic and international acquisition shows a more negative effect on domestic acquisitions. Lastly, this study found that acquirer resources have a more positive effect on acquisition success than target resources. Throughout the paper, various challenges acquirers face are provided in identifying, valuing, and utilizing target resources. All these factors hinder the ability of an acquirer to benefit from target resources. In contrast, acquirers have full control of their resources and, hence, benefit from them a lot more quickly after the acquisition.

This study makes several theoretical and empirical contributions. This is the first study that compares the effects of acquirer and target resources in acquisitions in an emerging country, Turkey. In addition to comparing acquirer and target resources, the study contains an analysis of the effects of resources on both domestic and international deals. No such comparisons have yet been made in the context of emerging markets so that the study provides new insights into acquisition research. Moreover, it extends the resource-based view of firms in terms of the role of resources in the success of acquisitions. This study shows that resources do not always improve acquisition success, especially target resources. This can be explained by a couple of factors, such as information asymmetry between an acquirer and a target, and postacquisition issues. The findings of this study also support arguments about the difficulty of assessing target resources before the acquisition and creating synergies afterwards. The results show that the effects of resources are not the same in domestic and international acquisitions. All these findings indicate that the relationship 
between resources and acquisition success is more complicated than it seems and that we need a better understanding of this relationship.

There are implications for practice here, especially in terms of how to approach acquisitions and resources. The benefits gained from acquirer and target resources are not the same. There is also a difference between domestic and international acquisitions regarding resources. All of these circumstances highlight the critical importance of performing due diligence before an acquisition. Companies should not be hesitant to allocate resources to due diligence process, especially when it comes to assessing target resources because identifying appropriate resources is critical to the success of an acquisition (Chen et al., 2018). Also, more effort should be spent on alleviating problems with post-acquisition integration, which has the potential to lower the creation of synergies.

Despite its use of a comprehensive sample, the study has some limitations. The choice of Turkey as the emerging market context to minimize variance across different markets resulted in a relatively small sample size. However, additional countries could be added to expand the sample. Due to limitations in the data, goodwill is used for target resources; other measures would yield better results, such as intangible target resources, which are hard to find in an emerging market context, especially for private firms. The study demonstrated that the impact of acquirer and target resources is not the same for domestic and international acquisitions, which opens new avenues of research for this stream of research. Some explanations are provided for why the impacts differ between the two types of acquisitions, but the underlying factors call for further study. Moreover, the underlying causes of differences between the effects of acquirer and target resources can be studied in the context of developed countries as well. 


\section{REFERENCES}

Akben, Selçuk E., \& Altıok, Yılmaz, A. (2011). The impact of mergers and acquisitions on acquirer performance: Evidence from Turkey. Business and Economics Journal

Akerlof, G. A. (1970). The market for "lemons": Quality uncertainty and the market mechanism. Quarterly Journal of Economics, 84(3), 488-500.

Al-Laham, A., Schweizer, L., \& Amburgey, T. L. (2010). Dating before marriage? Analyzing the influence of pre-acquisition experience and target familiarity on acquisition success in the "M\&A as R\&D" type of acquisition. Scandinavian Journal of Management, 26(1), 25-37. doi:10.1016/j.scaman.2009.11.005

Barney, J. (1991). Firm resources and sustained competitive advantage. Journal of Management, 17(1), 99120.

Bertrand, O., \& Zitouna, H. (2008). Domestic versus cross-border acquisitions: Which impact on the target firms' performance? Applied Economics, 40(17), 2221-2238. doi:10.1080/00036840600949397

Blonigen, B. A. (1997). Firm-specific assets and the link between exchange rates and foreign direct investment. American Economic Review, 87(3), 447-465.

Blonigen, B. A., \& Taylor, C. T. (2000). R\&D intensity and acquisitions in high-technology industries: Evidence from the us electronic and electrical equipment industries. Journal of Industrial Economics, 48(1), 47-70.

Boateng, A., Du, M., Bi, X., \& Lodorfos, G. (2019). Cultural distance and value creation of cross-border MEA: The moderating role of acquirer characteristics doi:10.1016/j.irfa.2018.12.009

Brockman, P., Rui, O. M., \& Zou, H. (2013). Institutions and the performance of politically connected $\begin{array}{lllll}\text { M\&As. Journal of } \quad \text { International } & \text { Business } & \text { Studies, } 44(8), 852 .\end{array}$ doi:http:/ / dx.doi.org/10.1057/jibs.2013.37

Butler, F. C., Perryman, A. A., \& Ranft, A. L. (2012). Examining the effects of acquired top management team turnover on firm performance post-acquisition: A meta-analysis Journal of Managerial Issues / PSU.

Caves, R. E. (2007). Multinational entreprise and economic analysis Cambridge University Press.

Chang, S., \& Tsai, M. (2013). The effect of prior alliance experience on acquisition performance. Applied Economics, 45(6), 765-773. doi:10.1080/00036846.2011.613767 
Chen, F., Meng, Q., \& Li, X. (2018). Cross-border post-merger integration and technology innovation: A resource-based view doi:10.1016/j.econmod.2017.07.012

Chen, Y., Hua, X., \& Boateng, A. (2017). Effects of foreign acquisitions on financial constraints, productivity and investment in R\&D of target firms in china. International Business Review, 26(4), 640651. doi:10.1016/j.ibusrev.2016.12.005

Colman, H. L. (2020). Facilitating integration and maintaining autonomy: The role of managerial action and interaction in post-acquisition cabability transfer. Journal of Business Research, 109, 148-160. doi:10.1016/j.jbusres.2019.09.063

Colombo, M. G., \& Rabbiosi, L. (2014). Technological similarity, post-acquisition R\&D reorganization, and innovation performance in horizontal acquisitions. Research Policy, 43(6), 1039-1054. doi:10.1016/j.respol.2014.01.013

Conyon, M. J., Girma, S., Thompson, S., \& Wright, P. W. (2002). The productivity and wage effects of foreign acquisition in the United Kingdom. Journal of Industrial Economics, 50(1), 85.

Cooney, J. W., Moeller, T., \& Stegemoller, M. (2009). The underpricing of private targets. Journal of Financial Economics, 93(1), 51-66. doi:10.1016/j.jfineco.2008.08.001

Cox, J., Taylor. (1991). The multicultural organization. Executive (19389779), 5(2), 34-47. doi:10.5465/AME.1991.4274675

Davies, R. B., Desbordes, R., \& Ray, A. (2018). Greenfield versus merger and acquisition FDI: Same wine, different bottles? Canadian Journal of Economics, 51(4), 1151-1190. doi:10.1111/caje.12353

Delios, A., Gaur, A. S., \& Kamal, S. (2009). International acquisitions and the globalization of firms from india. In J. Chaisse, \& P. Gugler (Eds.), Expansion of trade and FDI in asia strategic and policy challenges (1st ed., ) Routledge.

Demirbag, M., Tatoglu, E., \& Glaister, K. W. (2008). Factors affecting perceptions of the choice between acquisition and greenfield entry: The case of western FDI in an emerging market. Management International Review (MIR), 48(1), 5-38. doi:10.1007/s11575-008-0002-3

Dhanaraj, C., Lyles, M. A., Steensma, H. K., \& Tihanyi, L. (2004). Managing tacit and explicit knowledge transfer in IJVs: The role of relational embeddedness and the impact on performance. Journal of International Business Studies, 35(5), 428-442. doi:10.1057/palgrave.jibs.8400098 
Doukas, J. A., \& Kan, O. B. (2008). Investment decisions and internal capital markets: Evidence from acquisitions. Journal of Banking \& Finance, 32(8), 1484-1498. doi:10.1016/j.jbankfin.2007.05.017

Dunning, J. H. (1993). Multinational enterprise and the global economy Addison-Wesley, Harlow, U.K.,.

Dunning, J. H. (1998). The changing geography of foreign direct investment. In N. Kumar (Ed.), Internationalization, foreign direct investment and technology transfer: Impact and prospects for developing countries, London and New York: Routledge.

Dunning, J. (1981). Multinational production and the multinational enterprise George Allen \& Unwin, London.

Dyer, J. H., \& Singh, H. (1998). The relational view: Cooperative strategy and sources of interorganizational competitive advantage. Academy of Management Review, 23(4), 660-679. doi:10.5465/ AMR.1998.1255632

Dyer, J. H., Singh, H., \& Hesterly, W. S. (2018). The relational view revisited: A dynamic perspective on value creation and value capture. Strategic Management Journal (John Wiley \& Sons, Inc.), 39(12), 31403162. doi:10.1002/smj.2785

Edi Basri, Y. Z., Arafah, W. (2020). The effect of acquisition synergy on firm performance moderated by firm reputation.Journal of Accounting, Finance and Auditing Studies, 6(1), 16-32.

Genç, Ö. F. (2016). comparison of international and domestic acquisitions: A literature review. Journal of Management E Economics Research, 14(4), 128-149. doi:10.11611/yead.282052

Genc, O. F., \& Kalkan, B. (2018). Turkish mergers and acquisitions (m\&as): A historical view of characteristics, trends, and directions. International Journal of Management Economics \& Business / Uluslararasi Yönetim Iktisat Ve Isletme Dergisi, 14(3), 791-805. doi:10.17130/ijmeb.2018343123

Gomez-Mejia, L., \& Palich, L. E. (1997). Cultural diversity and the performance of multinational firms. Journal of International Business Studies, 28(2), 309-335.

Gubbi, S. R., Aulakh, P. S., Ray, S., Sarkar, M. B., \& Chittoor, R. (2010). Do international acquisitions by emerging-economy firms create shareholder value? the case of indian firms. Journal of International Business Studies, 41(3), 397-418. doi:10.1057/jibs.2009.47

Gubbi, S., \& Elango, B. (2016). Resource deepening vs. resource extension: Impact on asset-seeking acquisition performance. Management International Review (MIR), 56(3), 353-384. doi:10.1007/s11575016-0282-y 
Guerrero, S. (2008). Changes in employees' attitudes at work following an acquisition: A comparative study by acquisition type. Human Resource Management Journal, 18(3), 216-236. doi:10.1111/j.17488583.2008.00068.x

Gupta, D., \& Gerchak, Y. (2002). Quantifying operational synergies in a merger/acquisition. Management Science, 48(4), 517-533. doi:10.1287/mnsc.48.4.517.209

Haleblian, J., \& Finkelstein, S. (1999). The influence of organizational acquisition experience on acquisition performance: A behavioral learning perspective. Administrative Science Quarterly, 44(1), 2956.

Harrison, J. S., Hitt, M. A., Hoskisson, R. E., \& Ireland, R. D. (2001). Resource complementarity in business combinations: Extending the logic to organizational alliances. Journal of Management, 27(6), 679.

Haspeslagh, P. C., \& Jemison, D. B. (1991). Managing acquisitions: Creating value through corporate renewal New York, The Free Press.

He, W., Boateng, A., \& Ring, P. (2019). Motives, choice of entry mode, and challenges of bank internationalization: Evidence from china. Thunderbird International Business Review, 61(6), 897-909. doi:10.1002/tie.22062

Hitt, M. A. (2016). International strategy and institutional environments. Cross Cultural \& Strategic Management, 23(2), 206-215. doi:10.1108/CCSM-11-2015-0168

Hussinger, K. (2010). On the importance of technological relatedness: SMEs versus large acquisition targets. Technovation, 30(1), 57-64. doi:10.1016/j.technovation.2009.07.006

Huyghebaert, N., \& Luypaert, M. (2010). Antecedents of growth through mergers and acquisitions: Empirical results from belgium. Journal of Business Research, 63(4), 392-403. doi:10.1016/j.jbusres.2009.06.003

Ismail, A. (2008). Which acquirers gain more, single or multiple? recent evidence from the USA market. Global Finance Journal, 19(1), 72-84. doi:10.1016/j.gfj.2008.01.002

Jemison, D. B., \& Sitkin, S. B. (1986). Corporate acquisitions: A process perspective. Academy of Management Review, 11(1), 145-163. doi:10.5465/AMR.1986.4282648

Khanna, T., \& Palepu, K. (1997). Why focused strategies may be wrong for emerging markets. Harvard Business Review, 75(4), 41-51. 
Kim, J., \& Finkelstein, S. (2009). The effects of strategic and market complementarity on acquisition performance: Evidence from the us commercial banking industry, 1989-2001. Strategic Management Journal, 30(6), 617-646. doi:10.1002/smj.754

King, D. R., Bauer, F., (Derek) Weng, Q., Schriber, S., \& Tarba, S. (2020). What, when, and who: Manager involvement in predicting employee resistance to acquisition integration. Human Resource Management, 59(1), 63-81. doi:10.1002/hrm.21973

King, D. R., Dalton, D. R., Daily, C. M., \& Covin, J. G. (2004). Meta-analyses of post-acquisition performance: Indications of unidentified moderators. Strategic Management Journal, 25(2), 187-200. doi:10.1002/smj .37I

King, D. R., Slotegraaf, R. J., \& Kesner, I. (2008). Performance implications of firm resource interactions in the acquisition of R\&D-intensive firms. Organization Science, 19(2), 327-340. doi:10.1287/orsc.1070.0313

Krug, J., \& Hegarty, W. (1997). Post acquisition turnover among US top management teams: An analysis of the effects of foreign vs. domestic acquisitions of US targets. Strategic Management Journal, 18(8), 667675. doi:10.1002/(SICI)1097-0266(199709)18:8<667::AID-SMJ918>3.0.CO;2-E

Lamont, B. T., King, D. R., Maslach, D. J., Schwerdtfeger, M., \& Tienari, J. (2019). Integration capacity and knowledge-based acquisition performance. RED Management, 49(1), 103-114. doi:10.1111/radm.12336

Lee, G., Cho, S. Y., Arthurs, J., \& Lee, E. K. (2019). CEO pay inequity, CEO-TMT pay gap, and acquisition premiums. Journal of Business Research, 98, 105-116. doi:10.1016/j.jbusres.2019.01.023

Lin, Z., Peng, M. W., Yang, H., \& Sun, S. L. (2009). How do networks and learning drive M\&As? an institutional comparison between china and the united states. Strategic Management Journal (John Wiley E Sons, Inc.), 30(10), 1113-1132. doi:10.1002/smj.777

Liou, R., Rao-Nicholson, R., \& Sarpong, D. (2018). What is in a name? cross-national distances and subsidiary's corporate visual identity change in emerging-market firms' cross-border acquisitions. International Marketing Review, 35(2), 301-319. doi:10.1108/IMR-10-2015-0225

Madhok, A. (1997). Cost, value and foreign market entry mode: The transaction and the firm. Strategic Management Journal, 18(1), 39-61.

Maharaj, B., \& Reddy, M. (2013). To clear or not: Examination of mergers and acquisition cases from small economies. International Journal of Economics $\mathcal{E}$ Finance, 5(2), 125-140. doi:10.5539/ijef.v5n2p125 
Makri, M., Hitt, M. A., \& Lane, P. J. (2010). Complementary technologies, knowledge relatedness, and invention outcomes in high technology mergers and acquisitions. Strategic Management Journal, 31(6), $602-628$

Manne, H. G. (1965). Mergers and the market for corporate control. Journal of Political Economy, 73(2), 110.

Mukherji, A., Mukherji, J., Dibrell, C., \& Francis, J. D. (2013). Overbidding in cross-border acquisitions: Misperceptions in assessing and valuing knowledge. Journal of World Business, 48(1), 39-46. doi:10.1016/j.jwb.2012.06.005

Muratova, Y. (2015). The drivers of domestic acquisitions in people's republic of china: A resource-based analysis. Asia Pacific Business Review, 21(4), 500-516. doi:10.1080/13602381.2014.971639

Owen, S., \& Yawson, A. (2010). Human development and cross-border acquisitions. Journal of Empirical Finance, 17(4), 689-701. doi:10.1016/j.jempfin.2010.03.004

Piepenbrink, A., \& Gaur, A. S. (2013). Methodological advances in the analysis of bipartite networks: An illustration using board interlocks in Indian firms. Organizational Research Methods, 16(3), 474-496. doi:10.1177/1094428113478838

Popli, M., Ladkani, R. M., \& Gaur, A. S. (2017). Business group affiliation and post-acquisition performance: An extended resource-based view. Journal of Business Research,81, 21-30. doi:10.1016/j.jbusres.2017.08.003

Puranam, P., Singh, H., \& Zollo, M. (2006). Organizing for innovation: Managing the coordinationautonomy dilemma in technology acquisitions. Academy of Management Journal, 49(2), 263-280.

Ranft, A. L., \& Lord, M. D. (2000). Acquiring new knowledge: The role of retaining human capital in acquisitions of high-tech firms. Journal of High Technology Management Research, 11(2), 295. doi:10.1016/S1047-8310(00)00034-1

Reus, T. H., \& Lamont, B. T. (2009). The double-edged sword of cultural distance in international acquisitions. Journal of International Business Studies, 40(8), 1298-1316. doi:10.1057/jibs.2009.25

Rugman, A. M., \& Verbeke, A. (2004). A perspective on regional and global strategies of multinational enterprises. Journal of International Business Studies, 35(1), 3-18. doi:10.1057/palgrave.jibs.8400073

Rui, H., \& Yip, G. S. (2008). Foreign acquisitions by chinese firms: A strategic intent perspective. Journal of World Business, 43(2), 213-226. doi:10.1016/j.jwb.2007.11.006 
Saxton, T., \& Dollinger, M. (2004). Target reputation and appropriability: Picking and deploying resources in acquisitions. Journal of Management, 30(1), 123-147. doi:10.1016/j.jm.2003.01.006

Schijven, M., \& Hitt, M. A. (2012). The vicarious wisdom of crowds: Toward a behavioral perspective on investor reactions to acquisition announcements. Strategic Management Journal, 33(11), 1247-1268. doi:10.1002/smj.1984

Schmitz, P. W., \& Sliwka, D. (2001). On synergies and vertical integration. International Journal of Industrial Organization, 19(8), 1281.

Schweiger, D. M., \& Lippert, R. L. (2005). Integration: The critical ink in M\&A value creation. In G. Stahl, \& M. Mendenhall (Eds.), Mergers and acquisitions (pp. 17 - 46) Stanford: Stanford University Press.

Semerciöz, F., \& Çakınberk, A. (2003). Stratejik ittifaklar: Türk ilaç dağıtım kanalından bir örnek. Yönetim Dergisi, 14 (46): 23-39.

Stahl, G., \& Voigt, A. (2008). Do cultural differences matter in mergers and acquisitions? A tentative model and examination. Organization Science, 19(1), 160-176.

Steigenberger, N., \& Mirc, N. (2019). Should I stay or should I go? multi-focus identification and employee retention in post-acquisition integration. Human Relations., doi:https://doi.org/10.1177/0018726719847521

Vermeulen, F., \& Barkema, H. (2001). Learning through acquisitions. Academy of Management Journal, 44(3), 457-476. doi:10.2307/3069364

Wangerin, D. (2019). M\&A due diligence, Post-Acquisition performance, and financial reporting for business combinations. Contemporary Accounting Research,36(4), 2344-2378. doi:10.1111/19113846.12520

Wernerfelt, B. (2011). The use of resources in resource acquisition. Journal of Management, 37(5), 13691373. doi:10.1177/0149206310371693

Yang, J., Guariglia, A., \& Guo, J. (. (2019). To what extent does corporate liquidity affect M\&A decisions, method of payment and performance? evidence from china. Journal of Corporate Finance, 54, 128-152. doi:10.1016/j.jcorpfin.2017.09.012

Yildırım, C. (2017). Turkey' outward foreign direct Investment: Trends and patterns of mergers and acquisitions. Journal of Balkan and Near Eastern Studies, 19(3), 276-293. 
Yu, H., Dang, J., \& Motohashi, K. (2019). Post-M\&A technological capability-building of emerging market firms in china: The case of lenovo. Asia Pacific Business Review, 25(1), 40-60. doi:10.1080/13602381.2018.1513624

Zhou, Y. M. (2011). Synergy, coordination costs, and diversification choices. Strategic Management Journal (John Wiley \& Sons, Inc.), 32(6), 624-639. doi:10.1002/smj.889

Zollo, M., \& Meier, D. (2008). What is M\&A performance? Academy of Management Perspectives, 22(3), 5577. doi:10.5465/AMP.2008.34587995 